\title{
Interactive comment on "A study of the influence of tropospheric subsidence on spring and summer surface ozone concentrations at the JRC-Ispra station in northern Italy" by Pavlos Kalabokas et al.
}

\section{Anonymous Referee \#2}

Received and published: 30 September 2019

The article presents specific case studies to interpret the role of subsidence on high elevation surface ozone concentrations, with the synergy of different in situ and satellite observational data. Overall, the paper merits publication after a number of comments are taken into account:

In the abstract, a 10 year measurement period is mentioned, which creates a clear expectation that the results of this study are put in a long term context. This is not 
paper(s) should be included), the authors should provide some statistics on the extent at which their findings for 2011 are also typical for the rest of the years as well as some means of quantification (e.g. frequency, values during events versus average values).

The amounts of plots used is huge! The authors should definitely make a serious attempt either to merge few of them, or move to suppl. material, or exclude if really not needed. Those changes might need to be followed by changes in the text and the overall structure, which I leave upon the authors, yet few suggestions will follow immediately after in my review.

Finally, there are parts of the introduction or the results where references do not seem to be up to date, either in terms of time or space, the latter meaning references relevant to the area of interest. I have included few examples which I consider only indicative, but a more through review of the current state might be needed, and the selection remains at the discrete consideration of the authors.

Specific comments:

$\mathrm{Pg} 1$, Ln 30 - "It has been reported that tropospheric ... the last couple of centuries (Volz and Kley, 1988; Forster et al., 2007)." I would suggest that this introductory statement should be supported with more recent references.

Pg2, Ln 6 - "which might also be associated to deep tropospheric subsidence especially over the Mediterranean ... Kalabokas et al., 2013; Cooper et al., 2014; Safieddine et al., 2014; Kalabokas et al., 2015) ... especially for deep stratospheric intrusions the following references are very characteristic for the area and should be included in the already too long list of references, or later ( $\mathrm{Pg} 2$, lines 20-25). âĂć A deep stratospheric intrusion event down to the Earth's surface of the megacity of AthensApril 2012Meteorology and Atmospheric Physics 109(1):9-18, DOI: 10.1007/s00703-0100096-6 by Akritidis et al. âĂć Gerasopoulos E, Zanis P, Papastefanou C, Zerefos CS, loannidou A,Wernli $H$ (2006) A complex case study of down to the surfaceintrusions of persistent stratospheric air over the EasternMediterranean. Atmos Environ 40:4113-

Printer-friendly version

Discussion paper
Interactive

comment

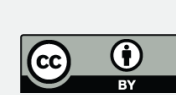


4125 âĂć Kentarchos AS, Davies TD, Zerefos C (1998) A low latitude stratospheric intrusion associated with a cut-off low. GeophysRes Lett 25:67-70

Pg 2, Ln 31 - It seems that two studies conducted at Finokalia remote station in the eastern Mediterranean, dealing with the dynamics and photochemistry of ozone are missing from the introduction, especially when discussing the eastern Mediterranean controlling mechanisms of surface ozone. On the contrary, there are many selfcitations from the first author that need to be enriched with studies from other groups in the area. âÁć Kouvarakis, G., K. Tsigaridis, M. Kanakidou, and N. Mihalopoulos (2000), Temporal variations of surface regional background ozone over Crete Island in the southeast Mediterranean, J. Geophys. Res., 105(D4), 4399 - 4407. âĂć Photochemical ozone production in the Eastern Mediterranean, June 2006, Atmospheric Environment 40(17):3057-3069, DOI: 10.1016/j.atmosenv.2005.12.061 by Gerasopouolos et al. âÁć Gerasopoulos, E., G. Kouvarakis, M. Vrekoussis, M. Kanakidou, and N. Mihalopoulos (2005), Ozone variability in the marine boundary layer of the eastern Mediterranean based on 7-year observations, J. Geophys. Res., 110, D15309, doi:10.1029/2005JD005991

Pg 3, Ln 15-17: Be7 reference for ambient levels are quite old, some inquiry on new articles reporting on the levels should be done, especially in the area of interest. The same in lines 21-23.

The information in section 2.2 should be better included in a table.

Figure $1 \mathrm{a}$ could be combined with $1 \mathrm{~b}$. The same stands for $2 \mathrm{a}, 2 \mathrm{~b}$.

Overall, the added value of this paper results is not clear and should be better highlighted, mostly in the conclusions. It is obvious that it is an extension of previous works and for that reason it needs to be clear where does this study starts from and where it ends up (added value) at the same time being a self standing scientific publication.

Interactive comment on Atmos. Chem. Phys. Discuss., https://doi.org/10.5194/acp-2019-438, 
2019.

ACPD

Interactive

comment

Printer-friendly version

Discussion paper 